\title{
Managing urban water crises: adaptive policy responses to drought and flood in Southeast Queensland, Australia
}

\author{
Brian W. Head $^{l}$
}

\begin{abstract}
In this case study, I examine the quality of decision-making under conditions of rapidly evolving urban water crises, and the adaptive policy challenges of building regional resilience in response to both drought and flood. Like other regions of Australia, Southeast Queensland has been subject to substantial cycles of drought and flood. I draw on resilience literature concerning sustainability, together with governance literature on policy change, to explain the changing awareness of urban water crises and the strategic options available for addressing these crises in this case study. The problem of resilience thinking opens up a number of important questions about the efficacy and adaptability of the policy system. The case provides insights into the interplay between the ways in which problems are framed, the knowledge bases required for planning and decision-making, the collaborative governance processes required for managing complex and rapidly evolving issues, and the overall capacity for policy learning over time. Regional resilience was proclaimed as a policy goal by government, but the practices remained largely anchored in traditional technical frameworks. Centralized investment decisions and governance restructures provoked conflict between levels of government, undermining the capacity of stakeholders to create more consensual approaches to problem-solving and limiting the collective learning that could have emerged.
\end{abstract}

Key Words: policy learning; regional resilience; urban water crisis; water governance; water policy

\section{INTRODUCTION}

Here, I provide a case-study of water management in Southeast Queensland (SEQ), an urbanized region on the Pacific coast of Australia. My focus is on explaining how the Queensland state government responded to climate variability, as manifested in rapidly shifting patterns of drought and flood in recent decades, with leaders characterizing these shifts as challenges to regional resilience. Similar types of resilience challenges have been widely experienced in many regions worldwide, and these experiences have required governments to review the adequacy of their policy frameworks and to adjust their governance arrangements by allowing a wider range of stakeholders to participate in the consideration of response options.

In SEQ, a series of water-related crises linked to the cycle of flood and drought has not only triggered significant policy changes, but has also provoked serious debates about the adequacy of these policy responses and has drawn attention to the need to strengthen regional resilience to shocks and stresses in the water sector. The key challenges are fundamentally about better identifying and managing major risks, balancing expert and citizen perceptions of problems and solutions, encouraging further cultural changes around water conservation, and developing an integrated longterm strategy taking into account the interplay between human activities and the natural environment.

First, I outline a conceptual framework that draws on theories of resilience, adaptive governance, and policy choice, and I propose this framework as a basis for understanding and explaining major policy changes in the SEQ case study. Second, I outline the range of data-gathering methods and analytical approaches that I used in the case study. Third, I outline the changing institutional context and policy choices relevant to the case study as background to a more detailed analysis of how and why policy and planning choices were made in response to the (very different) crises of drought and flood. Finally, I draw attention to the strengths and limitations of the policy directions and governance processes chosen by government decision-makers at various critical decision-points.

In concluding, I find that there was little transparency or openness in deliberations about new options. In general, the realization by top decision-makers that new options were needed was slow to emerge, despite the evident crises. At each stage, the range of choices was constrained by leaders' reliance on narrow conceptions of relevant historical experience and a desire for rapid reversion to business-as-usual. Despite policy innovations and the new language of "water resilience" and "climate-proofing" for this region, the technocratic organizational culture of urban water policy was not displaced.

\section{FRAMEWORK AND METHODS}

\section{Conceptual framework}

Resilience theories, while diverse in scope, are concerned firstly with understanding and assessing the capacity of a system (e.g., social-ecological) to respond successfully to major stresses, disturbances, or crises; and secondly, with identifying the effectiveness of relevant policy, regulatory, and planning frameworks (Folke 2006, Walker and Salt 2006, Norris et al 2008, Miller at el 2010). Resilience theories envisage dynamic change and disturbance as normal despite the apparent stability of a system at a given point in time. From a decision-making perspective, no assumption is made in resilience approaches that a simple return to the status quo ante is possible (or even desirable) following a major disturbance; rather, the focus is to identify key forms of adaptive management for responding effectively to changing conditions, with appropriate policies and programs for protecting key socioeconomic and ecological values.

Adaptive management and related policy concerns with implementation flexibility and stakeholder collaboration are based on a recognition that solutions are contextual and provisional (Walker and Salt 2006, Kiparsky et al. 2012). Rapid adjustments may be required as circumstances evolve. Where a 
system is vulnerable to deterioration, informed action to shift the policy regime may be required (Folke 2006, Gallopín 2006, Brown and Westaway 2011). However, this is difficult when institutional inertia and embedded practices serve to limit problem recognition, constrain choices, and inhibit new thinking. This tendency toward the institutionalization of preferred solutions and "path dependence" (Pierson 2000) may be challenged from time to time by external shocks or the emergence of new problems for which the old paradigm does not provide sufficient flexibility and protection. These opportunities for new thinking and adaptive learning (Pahl-Wostl 2009) are not always taken up, depending on local circumstances, including the degree of openness in the policy system and stakeholder engagement in issues management. Thus, the problem of resilience thinking opens up a number of important questions about the efficacy and adaptiveness of the policy system.

The literature on sustainable development, natural resource management, and land-use planning suggests that the scope and urgency of problems are intensified in an era of climate change coupled with continually growing demands for water, energy, and food security across the global community of nations (Gleik 2000, Molden 2007, Pahl-Wostl 2008, Holtz 2009, UNESCO 2009). Water-related policies and regulatory regimes have become a test case for the capacity of policy systems to deal with simultaneous challenges arising from increasing population, pressures on ecosystem services, and climatic change and variability, in the face of uncertain information and competing group interests. Much of the literature on regional resilience has focused on large-scale rural systems and mixed rural-urban regions, where the ecological aspects of natural resource management (e.g., water, soil, vegetation, and biodiversity values) are primary objects of analysis (e.g., see Allison and Hobbs 2004, Bohensky 2008, Walker et al. 2009). Large urbanized regions can also be analyzed from a resilience perspective, but the institutional and political context in which policy regimes operate and change over time are somewhat different. Here, I consider the dynamics of the urban water policy regime in a coastal region of Australia over a period of three decades.

\section{Case study approach and sources of information}

The present case study of SEQ provides a good example of how these pressures and challenges for regional resilience have played out in a relatively affluent urban region of Australia in recent decades. With this case study (Ragin and Becker 1992, Yin 2009), I do not aim to develop or test generalizable propositions about resilience dynamics, but I do seek to explore in depth the evolving policy dynamics of water-related problems of drought and flood in a metropolitan area of the developed world. The SEQ case exemplifies the difficulties faced by leaders in making complex choices with imperfect information in emerging water-related crises. I use the case to explore how leaders came to recognize and address a series of contrasting policy challenges, the changing governance arrangements for tackling these issues, the strengths and weaknesses of the chosen approaches, and the differences between the policy rhetoric and the realities of regional resilience. Some of these insights might have implications for comparative research about the ways in which context matters across different cases. Thus, the case exemplifies how water-related crises could be perceived and managed in very different ways and how policy learning may be deeply problematic under conditions of crisis management.
My analytical framework focuses on four major questions: (1) What were the major water-related challenges (or crises) confronted by decision-makers and stakeholders in SEQ? (2) How were these challenges framed or interpreted by decision-makers and what evidence/knowledge base did they use in their decisionmaking? (3) What governance processes, including stakeholder engagement, have underpinned decision-making on these water crises? (4) To what extent have policy innovations and adaptive frameworks for the region become embedded as a result of policy learning?

In answering these questions, several relevant sources of information were identified and analyzed. In relation to the history of water-related crises and the evolution of urban water policy in SEQ (and the broader policy contexts in Australia and internationally), I undertook literature searches on water policy at various scales of governance; considered public policy and regulatory documentation for the case study region and related scales within a federal system of governance; examined other background material such as media and political commentary on policy challenges and responses in SEQ; and undertook confidential interviews, some conducted through colleagues, with 60 senior and experienced stakeholders in local, state, and national government agencies, water utilities, and natural resource management groups. The qualitative material from the interviews was important for assembling key interpretations of how key actors in the SEQ water sector over three decades had understood the nature of the problems, their institutional constraints and opportunities, and the sources of change in policy and planning systems.

Using the case study, I provide an account of how and why policy changes occurred over time and note the limitations of these policies. Many contextual and institutional factors are important for understanding these policy settings, requiring an analysis of socioeconomic, political, technical, and organizational processes. Several alternative frameworks in policy studies are relevant to this case study, although I do not seek to test alternative policy theories. Common analytical features can be found in the general approaches of key analysts such as Kingdon (1995), Peters (2005), and Sabatier (2007) to inform the analysis of this case-study in water policy. These analytical features include a focus on (1) identifying the nature of the problems addressed by policy settings, (2) understanding the conditions under which new challenges are recognized and addressed, and (3) exploring the quality of the knowledge base and governance processes used in policy decision-making, during both normal or stable periods and in crisis conditions.

Policies implemented in a specific field (e.g., water, infrastructure, land-use programs) generally represent a dominant approach or paradigm that frames the problems that are seen to require attention and shapes the selection of appropriate instruments or solutions for these problems (Peters 2005). In this case study, I argue that particular approaches became institutionalized through a range of established routines, practices, and assumptions. Business-as-usual approaches are managed through standardized processes of planning, implementation, and monitoring, on the assumption that there will be a reasonable degree of continuity and stability in these processes. The evidence provided by technical experts, researchers, and practitioners is used to confirm and sometimes adjust the dominant framework 
(Head 2008). Using the case study, I examine the extent to which these business-as-usual assumptions were challenged by waterrelated crises and the extent to which the policy innovations that emerged from these crises addressed the underlying trends and challenges.

\section{CONTEXT AND BACKGROUND}

I begin by briefly outlining the broad debate about water policy and management trends. I then summarize the salient features of the case study area and its policy context.

\section{Water policy and management models}

In industrialized countries since the 1950s, the problem of providing reliable water supplies and sewerage services for large cities has been perceived primarily as an engineering challenge to be solved by technical experts through the construction of complex infrastructure systems based on large dams, trunk pipelines, and treatment plants (Brown et al. 2009). This powerful paradigm was seen to be addressing three related issues of water quality (public health), water security (reliability of supply), and sanitation (wastewater disposal). Parallel efforts were also taken over many decades by city engineers to mitigate the risk of major flooding of cities located in river basins; again, the favored methods were infrastructure works: dams, drainage channels, embankments, and diversions. This "dams and pipes" approach to securing water supplies, managing stormwater, and providing sanitation systems became the paradigm of urban modernization and was widely advocated internationally through professional networks of engineers, hydrologists, and water managers.

In several countries, this mainstream paradigm is being challenged as a result of further reflection on the continuing challenges of sustainability and experience with water-related crises linked to climate change. The basic argument is that the traditional engineering-based approaches, and associated technocratic decision-making processes, have been shown to be less effective in addressing increasingly complex water problems (Blomquist et al. 2004, Lach et al. 2005, Weber and Khademian 2008). A stream of longitudinal research addressing paradigm shifts in the water sector has been developed in the Netherlands and other European countries (see Van der Brugge et al. 2005, Van der Brugge and Rotmans 2007, Loorbach 2010). An alternative vision of collaborative water governance is gradually emerging, pointing to a series of phases characterized by local innovations and more participative and integrative approaches to problem-solving and sharing of information (Brown et al. 2009, Bos and Brown 2012). According to Loorbach (2010), the phases identified in such a transition toward more sustainable development may include "take-off, acceleration, and stabilization". The historical contrast between these two paradigms, technocratic versus sustainability, has been elaborated in European research. A stylized version of these contrasting paradigms is depicted in Table 1.

Some influential general frameworks concerning sustainable and integrated water management have been developed (e.g., European Commission 2000, 2009, Global Water Partnership 2000, 2008). However, none of these can be applied in identical ways across the full range of countries and regions; in particular, policy frameworks for sustainable water management cannot be implemented in exactly the same way across diverse regions because each has specific contextual features leading to different configurations in problem-solving.

Table 1. Traditional and future water management and planning styles.

\begin{tabular}{lll}
\hline \hline Characteristic & 1970s practices & $\begin{array}{l}\text { Post-2000 } \\
\text { requirements }\end{array}$ \\
\hline $\begin{array}{l}\text { Problem type } \\
\text { Planning approach }\end{array}$ & $\begin{array}{l}\text { Singular problem } \\
\text { Locality-based } \\
\text { technical planning } \\
\text { Solve today's problem }\end{array}$ & $\begin{array}{l}\text { Inter-related problems } \\
\text { System-based spatial } \\
\text { planning }\end{array}$ \\
$\begin{array}{l}\text { Anticipate tomorrow's } \\
\text { problems } \\
\text { strategy }\end{array}$ & $\begin{array}{l}\text { Discipline-specific } \\
\text { Skills requirements } \\
\text { professional skills } \\
\text { professional skills } \\
\text { Participants }\end{array}$ & $\begin{array}{l}\text { Engineers, biologists, } \\
\text { public managers, } \\
\text { urban and social } \\
\text { planners, etc. } \\
\text { Networks, } \\
\text { participation, and } \\
\text { inclusion }\end{array}$ \\
Governance approach & $\begin{array}{l}\text { Hierarchical, top- } \\
\text { down governance }\end{array}$ & \\
\hline Source: Adapted from & Van der Brugge and Rotmans (2007:261).
\end{tabular}

\section{Australian water sustainability frameworks}

In Australia, as in many countries, the scientific evidence about environmental degradation of both urban and rural waterways gradually became more compelling since the 1980s. This evidence, combined with more recent declines in water availability in some regions, led to significant shifts in the perceived policy problems that demanded attention (Dovers and Wild River 2003, Hussey and Dovers 2007). In the light of water scarcity, pressures arose for new strategic directions, focusing on ecosystem health, water efficiency, demand management, and new collective frameworks that would allow burden-sharing and trade-offs among stakeholder interests. These factors highlighted that the knowledge base needed to be expanded to ensure high-quality decision-making on more complex inter-related issues. In other words, engineering expertise alone could not resolve future policy directions, and increasing attention would have to be accorded to the socioeconomic, community, and institutional dimensions of water policy and management (Colebatch 2006, Head 2010, Wallington et al. 2012). The inter-related nature of the problems, and the uncertainties concerning future weather patterns, led to a need for more interactive and integrated approaches to scoping the issues and to sharing knowledge concerning how to tackle complex and wicked problems (Head and Alford 2014).

In Australia, water policy has been a state government responsibility. There has been a distinct bifurcation between rural and urban water governance frameworks (Pigram 2007). Rural water systems, especially the major river basins that support the irrigated agriculture industries such as the massive MurrayDarling basin river system, became objects of policy attention because of the complexities of cross-border jurisdictional conflict in a federal system and because of the conflicting interests of economic development and the ecological health of river systems (Connell 2007). National water policy frameworks (Australian Government 2004, 2008) arose primarily from the perceived need to achieve a more consistent approach to rural water as a scarce resource. Rural industry water is the dominant form of water use 
in Australia owing to the importance of irrigated agriculture. Water for cities was at best a policy afterthought in these national documents. The federal government has recently adopted a stronger role in strategic policy and has provided financial incentives for efficiency initiatives and for developing alternative water sources. A report to the Prime Minister in 2007 urged more attention to risk management for securing urban water supplies (Prime Minister's Science Engineering and Innovation Council 2007).

Urban water had attracted little government policy attention at the national level until the prolonged drought of the 2000s radically changed perceptions (Troy 2008). Essential services for the large cities were the responsibility of state governments, along with subsidiary roles for local authorities. Since the late 1980s, the managerial efficiency of urban and rural water authorities had been a matter of increasing concern. Government-owned water utilities were corporatized and commercialized, especially from the mid-1990s, when all public utilities were subjected to competition policy reforms to improve their efficiency and accountability. The user-pays principle for water pricing was gradually introduced. National and state policy initiatives led to commercialization and restructuring of water and energy monopolies, and there has been pressure from pro-market lobbyists to press for further commercialization and privatization (Productivity Commission 2008). With the corporatization of public utilities since the 1980s, state-owned water corporations were responsible for water supply systems for large metropolitan areas such as state capital cities (Pigram 2007). For example, in the state of Victoria in the $1990 \mathrm{~s}$, a reformist business-oriented government expedited the restructuring of water utilities, leading to a sharp awareness of the potential contradictions between commercial objectives, risk-taking, public sector accountability, and serving both its customer base and its government owners (Sadler 1998). In Queensland, the process of corporatization proceeded more slowly but followed a similar pathway.

\section{Water governance in Southeast Queensland}

SEQ shares some similarities with other regions of Australia and internationally, but has a number of unique features that provide insights into the dynamics of policy change. The SEQ region, which includes the Queensland state capital city of Brisbane, covers a coastal strip approximately $220 \mathrm{~km}$ long and $100 \mathrm{~km}$ wide (Fig. 1). The waterways of SEQ drain toward the east coast, with river basins flowing through Brisbane and the coastal tourism areas of the Gold Coast and Sunshine Coast. The SEQ region is one of the fastest-growing areas of Australia, with major demands for water, energy, transport, housing, and construction services. With a rapidly growing urban population of $>3$ million residents, water consumption in SEQ is largely urban (70\%). Fertile floodplain areas that had been used for agriculture a century ago have been progressively re-zoned for urban residential and commercial development throughout the 20th century. Population growth and associated services have been the major drivers of the regional economy. The state of Queensland has been notable for its pro-development ethos and its promotion of natural resource exploitation. The highly urbanized Southeast region has been a major focus of the property development, urban services, and coastal tourism industries. Since the 1970s, rapid growth in population has continued to drive demand for social and physical infrastructure services, with resultant pressure on environmental assets and natural resources, including water quality and water supply (Cole 1984, Gleeson and Steele 2010). The private sector has long held the key entrepreneurial role, but the state and local levels of government have also played entrepreneurial booster roles (Harvey 1989, Caulfield and Wanna 1995) in facilitating and promoting investment, building infrastructure, and improving amenities for citizens.

Fig. 1. Map of the Southeast Queensland region, Australia, showing major rivers and catchments.

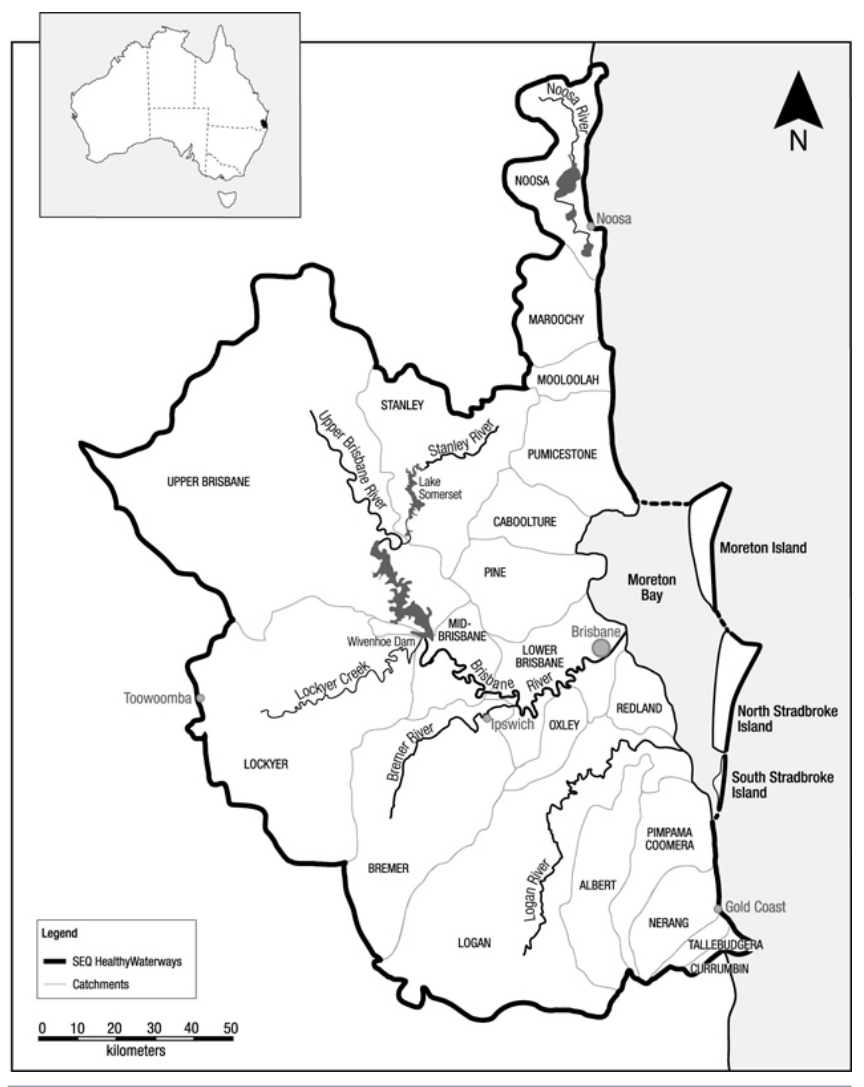

Water supplies for urban areas (i.e., households and industrial users) in SEQ have been almost entirely dependent on water drawn from large reservoirs in river valleys. There is no significant body of high-quality groundwater. These reservoirs, constructed by state and local government authorities, have also served as frontline flood mitigation facilities. For the remaining areas of irrigated agriculture, farmers have generally drawn water directly from local waterways, although irrigation entitlements have recently been subjected to water resource planning and licensing regimes that constrain allocations and that increasingly reflect the real costs of supply. In terms of public management responsibilities in a federal three-tier structure, local authorities have, until recently, owned and operated the smaller local water storage and treatment facilities, whereas the state government has coordinated overall water planning and has substantially funded the larger infrastructure required for major cities.

Responsibilities for water supply, stormwater, and sewerage services in SEQ have historically been mainly a local government 
matter. The local level of government has been reconfigured or restructured on several occasions, but for much of the period under analysis, there were 18 local government authorities in the SEQ region. One local authority has been predominant: the City of Brisbane, a large, integrated, metropolitan authority established in 1924, now with $\sim 1$ million residents. A regional Water Board owned many of the water infrastructure assets on a shared equity base of 80:20 between local and state government interests. This shared equity arrangement continued when the Board was commercialized in 2000 as the SEQ Water Corporation. This shared governance model of water system ownership and management came under pressure during the recent crises of drought and flood and was transformed during 2007-2008.

\section{RESPONDING TO WATER CRISES IN SOUTHEAST QUEENSLAND}

I next report on the policy and planning challenges of flood and drought recently addressed by water policy-makers and water managers in SEQ, as well as the policy and planning responses of the state government, whose leaders came to a growing realization that new options were needed.

By way of summary, the water policy and management challenges have increased in recent decades as the long-term cycles of drought and flood have intensified and the economic impacts of disruption have become more costly within highly urbanized areas adjacent to floodplains. In response to a major flood in 1974, with widespread inundation of urban areas, the government's policy response centered on flood-mitigation engineering and construction of a large new dam, which was increasingly viewed as "flood-proofing" the capital city of Brisbane. However, in 2001-2008 the opposite problem occurred, with a severe drought pattern threatening a crisis in urban water supplies. The government's policy response emerged only slowly as the crisis deepened and led to a wide range of expensive supply-side projects to improve water security along with some new demandmanagement programs. The state government also reformed urban water policy governance, with major restructuring and centralization of urban water decision-making. The region survived the drought, assisted by the return of more normal rainfall patterns in early 2009 , at which point the government abandoned water restrictions and water-recycling initiatives. Two years later, the region encountered a major flood similar in scale to 1974 , raising debates about the adequacy of previous flood mitigation planning, the continuing market-driven patterns of urban growth, and the appropriate measures for sustainable water planning and management across a range of disaster scenarios.

\section{Floods, droughts, and the emergent sustainability agenda in Southeast Queensland}

SEQ is located in a sub-tropical zone that fluctuates between a temperate weather pattern with modest rainfall and a more turbulent weather pattern with storms and cyclonic rain stemming from weather systems in north Queensland. The established primary focus of water planners had been to secure adequate supplies of water through the construction of dams. Gradually, the availability of suitable new sites was diminished; the best sites were taken up either by existing water storage, which were periodically enlarged wherever feasible, or by peri-urban residential encroachments, which became too expensive for resumption for alternative uses. Water engineers and political leaders were broadly aligned with this approach, despite occasional public controversy around where to locate a particular storage (Pullar and Cook 2001). For example, an attempt to build a new dam on the Albert River in the Gold Coast hinterland at Wolffene was unsuccessful; the construction proposal was overturned in 1990 by a new state government that had seen the proposal as unpopular with local constituents (Queensland Parliamentary Debates, March 1, 1990).

The last successful dam-building project in SEQ was the Wivenhoe dam, completed in 1984 on the upper Brisbane River. This project was notable for being triggered by a renewed concern with flood mitigation. Severe flooding had occurred periodically in SEQ, most notably in 1857, 1893, 1931, and 1974. After the 1974 cyclone produced major flooding in coastal SEQ, the focus of political and professional attention shifted to flood mitigation infrastructure, and a major dam was commissioned in the late 1970s, primarily for this purpose (Cole 1984, Pullar and Cook 2001). Wivenhoe dam captured rainfall only from the upper catchment of one river flowing into the Brisbane basin, but its vast size created a double illusion: first, that major risks of flooding had been solved for Brisbane, and second, that SEQ would have water abundance once the new dam was filled. The illusion that SEQ had abundant water was reflected in water metering practices. In Brisbane, for example, the proportion of properties with water meters was very low in the 1980s, when < $10 \%$ of households had information about their water consumption levels (Spearritt and Head 2010).

With dam-building seen as a lower priority in the 1990s, other issues in water management became increasingly prominent. National policy debates had been placing more attention on sustainable development and more integrated approaches to landuse and natural resources. In rural areas and the urban fringe, movements to promote integrated catchment management and "Landcare" emerged, with government financial support. Landholders in many catchments or river basins were encouraged to manage their properties more carefully to protect biodiversity and to avoid pollution of waterways arising from soil erosion and overuse of fertilizers and pesticides. These initiatives became linked, with growing political and scientific focus on the ecological health of urban waterways. In a short time, the issues of chemical pollution and nutrient loads in urban rivers, bays, and estuaries, with their implications for human health and aquatic biodiversity, became major matters of public concern in the late 1990s. A broad coalition of environmental groups emerged to support "healthy waterways", focusing on water quality rather than quantity. These demands for clean catchments and waterways were channelled into the environmental objectives of the SEQ regional planning framework that was initiated in the mid-1990s. The environment and natural resource dimensions of this emerging framework were supported politically through an alliance of local councils, state agencies, environment groups, and scientists, which was known later as the Healthy Waterways Partnership (Healthy Waterways Partnership 2007). With funding and policy support from the state and federal governments, this alliance achieved the upgrade of 25 sewerage treatment plants to reduce wastewater pollution in rivers and coastal waters. Having achieved this specific objective, they turned their attention to the broader sources of water pollution, especially from industrial waste discharges and the nutrient and 
chemical runoff from farmlands. The Partnership developed a more consensual model for approaching these broad objectives and used an annual audit of water quality in SEQ rivers as a powerful instrument of public accountability.

Legislative changes reinforced the new interest in sustainable use of resources, including a new Queensland Water Act in 2000. Each catchment or river basin was required to develop a water resources plan, in part to meet the state's obligations under the 1994 nationally agreed water strategy (Pigram 2007). These catchment plans required scientific input and stakeholder consultation to assess future water availability and the respective needs of rural industries, urban industries, and residential consumption. This legislation also provided the foundation for gradually moving toward implementing the cost-efficiency and user-pays principles of the 1994 national water agreement and its update in 2004 (Australian Government 2004).

The interest in ecological sustainability, and its more collaborative processes for community engagement, was gradually overshadowed by the emergence of a long drought from 2001. Apart from occasional supply problems leading to restrictions on water-sprinkling for suburban gardens, there had been little urgency previously accorded to major urban water supplies. The supply-side problems were beginning to become evident owing to a combination of the fast-growing population (a factor already included in state water planning forecasts) and an unpredicted shift toward drastically lower rainfall patterns from 2001. The deterioration of water supply security over the period 2001-2008 was a creeping crisis rather than a sudden event (B. W. Head, unpublished presentation, International Research Society for Public Management Conference, Copenhagen, 6-8 April 2009), and this deepening trend caught the political and policy systems unprepared. Water restrictions were seen as politically unpopular, but had been apparently sufficient to deal with previous water shortages. As the water levels of the major dams in SEQ continued to fall to $<20 \%$, and as other major cities in Australia came to experience similar difficulties, the term "millennium drought" was coined to describe the severity and unpredictability of the experience (Spearritt and Head 2010).

While political leaders initially avoided taking responsibility for tackling the emerging issues, the water policy bureaucrats began to publish more detailed scenarios based on lower rainfall projections as a basis for attracting the strategic attention of leaders (Queensland Government 2004, 2005). As the risks intensified, a wider range of possible water security measures was floated by policy bureaucrats. However, the attempts to raise the stakes were not initially successful, and the creeping crisis continued without significant interventions. The co-operative and devolved arrangements for water planning and decision-making eventually came under great pressure in 2006. State and local authorities became alarmed by the deteriorating water-supply outlook, but a joint solution seemed out of reach at the political level.

The centralist policy solutions taken by the state government in 2006-2007 are outlined and analyzed below. Here, I focus on how the problem underlying the water-related crisis was perceived, and the implications for who needed to take action. The crisis was portrayed as a supply-side crisis that could only be resolved by securing additional supplies of drinking-quality water, thus reinforcing the engineering and infrastructure paradigm of water planning with centralist solutions driven by project financing. Following the major policy and organizational changes initiated by the state government, two further years were devoted intensively to upgrading water infrastructure, thus implementing the crisis management measures for water security. During this period, all other water-related issues and priorities were displaced. Securing the urban water supply was the dominant objective in the policy agenda.

In late 2008, there was a modest return to seasonal rainfall, and by early 2009 , a state election was looming. The government then pronounced that the water crisis was over. Water restrictions were moderated, and the imminent prospect of introducing potable recycled water was deferred. In focusing on key issues for the 2009 state election, the government wished to avoid unpopular policy measures. By this time, economic issues about jobs and investment had come to the foreground of policy attention because the global financial crisis had swept away the normal expectations of economic growth and prosperity. Governments were also concerned about controlling their burgeoning public debt, exacerbated by the recent investment in new water infrastructure facilities, and some modest subsidies for water efficiency programs were withdrawn as a savings measure.

In late 2010 and early 2011, the policy attention cycle changed yet again. A series of unusual weather conditions (Van den Honert and McAneney 2011) produced major flooding in many parts of Queensland, generating large-scale social and economic disruption. In SEQ, the Brisbane catchment experienced severe flooding, with 20,000 homes inundated and infrastructure destroyed; in some upstream towns, lives were lost in flash floods. Insurance claims of AUD \$2.4 billion were lodged, and additional public sector expenditure of approximately AUD\$5 billion was incurred for flood recovery services and the repair of social and physical infrastructure, assisted by federal disaster relief funding (National Climate Change Adaptation Research Facility 2013). Political leaders of all backgrounds temporarily united to focus on emergency management procedures and to coordinate the work of large numbers of volunteers to assist the emergency services organizations with the massive clean-up. Soon, however, the spirit of unity dissipated as politicians began the blame game. Many residents complained that they had not been properly compensated by insurance companies, which quibbled about the definition of flood, and many others complained that town planning approvals and flood mitigation measures should have better protected them from the floods. There was an understandable focus on explaining why the large dam at Wivenhoe had not saved the city, and a Commission of Inquiry was established in 2011 (see Queensland Floods Commission of Inquiry 2012). Fanned by the media, there was a forensic examination of the conduct of water engineers who had released additional water from Wivenhoe just before dam storage levels became dangerously high, thereby worsening the downstream flooding caused by other rivers in the catchment.

\section{Choosing policy solutions: innovation and path dependence}

I next analyze the policy responses to these water-related crises and the limits on innovation. The fluctuating policy attention cycle outlined above demonstrates the difficulties of maintaining focus on important strategic issues. Water as a policy issue was 
backstage during much of the period under discussion but came to the foreground in four different guises over time: the creeping crisis of urban water security during the long drought of 20012008, the sudden major flooding events of 1974 and 2011, the steady regional water planning processes undertaken in each river basin after the Water Act of 2000, and the multi-stakeholder initiatives by the Healthy Waterways Partnership to clean up the rivers and bays. The policy responses were shaped by different understandings of the key issues for water policy in SEQ and were implemented through different governance arrangements. In general, both the water experts who provided policy advice for both water supplies and flood mitigation and those who provided design advice for dam construction were drawn from the same networks of civil engineers, hydrologists, and infrastructure consultants, i.e., those who had shaped the orthodox paradigm of solving problems through large infrastructure projects. Under conditions of emerging crisis, whether in flood or drought, the government turned first to these technical experts.

Thus, in the aftermath of the 1974 Brisbane floods, the preferred solution agreed on by government was a large and expensive dam project that took nearly a decade to complete (Cole 1984, Pullar and Cook 2001). When a similar flood scenario was repeated in 2011, it became evident that a single dam on one river was insufficient to harness a massive rain event, and that the issues generated by a major flood were many and varied and beyond the purview of dam engineers. For example, in terms of urban planning, little attention had been given to reserving low-lying areas for recreational uses rather than residential and industrial uses, and planning errors from earlier decades were compounded rather than resolved. Other issues arose concerning disaster relief and emergency management coordination, where it became clear that large-scale contingencies had not been anticipated and risk communication with vulnerable groups had been inadequate (Queensland Floods Commission of Inquiry 2012). Widespread controversies also arose over insurance, compensation, and liability for losses, with insurance companies refusing to cover damage from upstream (regional) sources rather than from localized downpours. Social security systems and charitable services for displaced families were overloaded. The state government's response to the loss of critical infrastructure in the flood was a pledge to rebuild it all, although in some instances the designs were to be modified or the location adjusted. The overall problem was identified as flood mitigation improvement through infrastructure protection. Alternative framings were ignored such as those based on international research (e.g., Godschalk 2003, Krysanova et al 2008, Jonkman and Dawson 2012, Tierney 2012), which focus on prevention strategies and greater attention to land uses in flood-prone areas. The Commission of Inquiry considered the adequacy of the emergency management arrangements during 2011-2012. The former director-general of the department of community safety complained that this Inquiry represented a missed opportunity to examine the fundamentals of improving community resilience and developing prevention approaches, rather than placing a primary emphasis on the adequacy of the response and recovery measures (McGowan 2012).

The greatest degree of policy innovation was triggered by the extended experience of drought. These policy decisions may be grouped in terms of (1) governance and institutional arrangements (re-structuring), (2) infrastructure investment measures, and (3) demand-management (or behavior change) measures.

First, the state government initiated a series of major changes in water governance in 2006. It established a statutory body, the Queensland Water Commission, to centralize water strategy responsibilities. With the assistance of consultants, it developed a new centralized governance model for the water industry in SEQ (see Queensland Water Commission 2007), including divestment of local government roles in water management, integrated state ownership of water assets, and functional separation between responsibility for water storage and treatment facilities and responsibility for the new regional water grid (trunk pipeline network). Local authorities retained their roles in managing stormwater and sewerage treatment and also in the water retail business. The cooperative models for water planning and for joint ownership of water assets that had operated in the late 1980s through the 1990s became discredited around 2005-2006 as the prolonged drought deepened and as state/local conflict emerged at the political level(Head 2010). The state government concluded that, in the face of a planning crisis, responsibilities had become unclear, local authorities were too weak or fragmented to solve the problems, and that centralization of authority was necessary. This decision created a high level of political distrust and conflict, heightened by a process of amalgamations of local authorities during 2008, with an overall reduction in the SEQ region from 18 to 10 .

Second, the state government promised a number of new water infrastructure facilities. These took several forms. A major pipeline network was built in 2007-2009 to facilitate transfers between storages or catchments across the region. This would have been difficult without centralization of power, owing to the likely parochialism of local stakeholders. In relation to dam construction, the government enlarged the storage capacity of some regional reservoirs and proposed to construct a new dam on the Mary River at Traveston (beyond the northern boundary of the SEQ region). Considerable funds were spent on preliminary planning and acquisitions for the proposed dam until the federal government surprisingly vetoed the proposal in November 2009 on environmental grounds, having determined that biodiversity protection requirements could not be met. All the government's supply-side and demand-side measures from this period are summarized in Table 2.

Two other important supply-side options were also announced in 2006-2007: a desalination plant and a potable recycled water facility. A desalination plant was commissioned, to be built and managed under contract by the private sector, to produce potable water at Tugun on the Gold Coast. The high quality water would be fed into the regional network as required. This facility generated environmental criticism in relation to energy costs and high saline discharges, but it commenced operation in early 2009; it initially supplied cooling water for state power stations (which, to the considerable embarrassment of government, had previously been using potable water from reservoirs). However, the plant was mothballed within two years owing to heavy rainfall throughout SEQ (Brisbane Times, December 5, 2010). Its utility was briefly revived during the flood of early 2011, when some other water sources had become polluted, but it was closed soon 
Table 2. Available policy responses to water scarcity.

\begin{tabular}{ll}
\hline \hline $\begin{array}{l}\text { Supply-side responses directed at establishing augmented and alternative } \\
\text { water supplies }\end{array}$ & $\begin{array}{l}\text { Demand-side responses directed at reducing water consumption through } \\
\text { demand-management measures }\end{array}$ \\
\hline - New dams & • Water restrictions (e.g., limits on certain water uses and hours of water \\
- Increase capacity of existing dams & use) \\
- Water grid pipelines & - Installation of water-efficient devices \\
- Desalination plant & - Water metering \\
- Advanced wastewater purification plant (recycled water facility) & • Larger industrial water-users required to adopt best-practice water \\
- Stormwater capture for industrial and parkland re-use & conservation standards \\
- Incentives for domestic and industrial rainwater tanks & • Higher water prices to ensure full cost recovery \\
- Aquifer recharge where feasible & • Consumption targets for households, localities, and industry sectors \\
& • Information, education, and publicity concerning water use
\end{tabular}

afterward. It was regarded as an insurance option for future crises. An even more controversial innovation was state investment in potable recycled water (PRW). Previous attempts by local authorities to implement PRW at a local scale had been rejected by local residents and by the state government (Uhlmann and Head 2011). At the height of the drought in 2007-2008, an advanced wastewater treatment plant producing potable recycled water was built at Bundamba near Ipswich. Other advanced sewerage treatment plants, producing industrial-quality water, were built to reduce industry use of potable water and to reduce nutrient discharges into waterways. The Bundamba PRW plant was linked via the new water grid to several potential industrial users, e.g., power stations and agriculture, but most notably it was linked to the Wivenhoe dam. Despite the well-known lack of public support for PRW, the government announced in 2007 an intention to feed PRW into Wivenhoe as an emergency measure once the new plant and pipeline grid were fully operational. However, the final decision was delayed owing to steady rainfall in late 2008 and through the months leading up to the state election in March 2009. Because reservoir volumes rose to more than half their capacity, it was announced that PRW would only be reconsidered if reservoir levels fell to $<40 \%$ (Spearritt and Head 2010).

Finally, the state government's policy responses to the urban water crisis included a range of demand-management and water conservation measures. Water restrictions were regarded as politically unpopular but had commonly been applied in various periods of reduced water availability, and these restrictions were intensified as the urban drought continued after 2002. Because these restrictions mainly affected residential outdoor water uses (e.g., for gardens, pools, and car-washing), it was necessary to engage consumers in a more thorough program of voluntarily reducing their total water use. A marketing campaign by the Queensland Water Commission, supported strongly by the mass media, attempted to persuade residents to extend their water conservation to indoor uses and to reduce daily per capita consumption to $<140 \mathrm{~L}$ (which was half the historical norm). Targeted reductions were practicable only if there was good information for each household; fortunately, water metering had become universal since the 1990s, and price increases were beginning to provide incentives for restraint. The campaign was extremely successful, with targets met and wide community support for water conservation to achieve collective goals. Even more remarkably, the behavior changes largely survived the drought, with average per capita consumption in 2011-2012 approximately $160 \mathrm{~L}$. Other incentive programs to reduce consumption included subsidies for water-efficient household plumbing (taps, showers) and for domestic rainwater tanks. Larger businesses using $>10^{7} \mathrm{~L} / \mathrm{yr}$ of town water were also drawn into the new regulatory arrangements. They were required to implement a water efficiency management plan based on industry best practice.

In the following section, I consider the significance of these measures and their relationship to the debate on regional resilience under conditions of perceived crises.

\section{REGIONAL RESILIENCE AS STRATEGY AND AS PRACTICE}

Even though public authority had been centralized to ensure effective and rapid implementation of the new water policy regime, there was weak political capacity to drive potentially unpopular decisions as the crisis diminished, and several innovations in relation to water conservation and recycled water were abandoned when normal conditions returned and the political pressure was reduced. The language of regional resilience was gradually adopted by political leaders, but much of this was symbolic. As noted by Healey et al. (2003:67), the new rhetoric is not always translated into institutionalized practices, remaining as "ripples on the surface of a settled modality of governance". The fragmented and uneven patterns of policy learning were reflected in the evolution of important strategy documents; these texts suggest that policy change was uneven and episodic and that reversion to more familiar patterns was a realistic possibility. The complete package of measures generated in SEQ during 20062009 in response to the drought was incorporated into successive drafts of a Water Strategy for Southeast Queensland (Queensland Water Commission 2010). This thinking also fed into the water management section of the broader SEQ Regional Plan (Queensland Government 2009). However, very few of the policy lessons were locked in, and several innovations developed during the drought crisis were discontinued. The overall patterns of water policy developments over three decades in SEQ, in the wider context of concerns about economic growth and sustainable development, are summarized in Table 3.

One important insight emerging from the SEQ experience was the enduring success of demand-management measures in reducing water consumption. Indeed, this group of measures demonstrated 
Table 3. Changing frameworks in the urban water sector, Southeast Queensland, Australia, since the 1970s.

\begin{tabular}{|c|c|c|c|c|}
\hline $\begin{array}{l}\text { Time } \\
\text { period }\end{array}$ & $\begin{array}{l}\text { Major paradigm for regional } \\
\text { policy }\end{array}$ & Major perceived water challenge & $\begin{array}{l}\text { Major paradigm for water } \\
\text { policy }\end{array}$ & Policy learning \\
\hline $\begin{array}{l}1970 s- \\
1980 s\end{array}$ & $\begin{array}{l}\text { Promote economic growth and } \\
\text { expand population }\end{array}$ & $\begin{array}{l}\text { Build new dams for both water } \\
\text { supply and flood mitigation } \\
\text { (post-1974 experience) }\end{array}$ & Build new water storage & $\begin{array}{l}\text { Business-as-usual is sufficient, } \\
\text { but need to manage rare major } \\
\text { floods }\end{array}$ \\
\hline $1990 \mathrm{~s}$ & $\begin{array}{l}\text { Seek better management of } \\
\text { growth through more integrated } \\
\text { planning }\end{array}$ & $\begin{array}{l}\text { Fewer sites available for new } \\
\text { dams }\end{array}$ & $\begin{array}{l}\text { Augment existing dams; trend } \\
\text { toward commercialization of } \\
\text { water utilities }\end{array}$ & $\begin{array}{l}\text { Integrated planning is an } \\
\text { attractive goal but very difficult }\end{array}$ \\
\hline $\begin{array}{l}2001- \\
2008\end{array}$ & $\begin{array}{l}\text { Growth management through } \\
\text { the lens of sustainable } \\
\text { development }\end{array}$ & $\begin{array}{l}\text { Growing awareness of water } \\
\text { security crisis (water scarcity) }\end{array}$ & $\begin{array}{l}\text { Centralization of water assets } \\
\text { and planning; new policy } \\
\text { options briefly explored }\end{array}$ & $\begin{array}{l}\text { Future risk mapping and } \\
\text { management requires greater } \\
\text { attention }\end{array}$ \\
\hline $\begin{array}{l}2009- \\
2013\end{array}$ & $\begin{array}{l}\text { Growth is good during a global } \\
\text { recession }\end{array}$ & $\begin{array}{l}\text { From scarcity to over- } \\
\text { abundance (floods of early } \\
\text { 2011) }\end{array}$ & $\begin{array}{l}\text { Some policy innovations } \\
\text { abandoned in 2009-2011; flood } \\
\text { disaster systems under critical } \\
\text { scrutiny }\end{array}$ & $\begin{array}{l}\text { Brief period of policy } \\
\text { consolidation (Water Strategy) } \\
\text { followed by change of state } \\
\text { government and blame game }\end{array}$ \\
\hline
\end{tabular}

massive financial benefits, namely, the deferral of future investment in new supply-side infrastructure such as additional desalination plants. Propositions concerning the efficacy of demand management had been criticized strongly as dangerous idealism by the infrastructure lobbies proposing new infrastructure solutions such as the Traveston dam. In a technical submission to a federal Senate inquiry into the water needs of the Mary River region, environmental research consultants (Turner et al. 2007) had claimed that a concerted program of water conservation and water efficiency could have deferred the need for an expensive new reservoir in or near SEQ. This argument was fiercely rejected by project consultants for the project and by the government, which had announced its commitment to building the dam. The proven benefits of water conservation from 20062009 were later factored into the SEQ Water Strategy in 2011, deferring by a decade the likely need for further water supply capacity.

Other significant innovations from this period, i.e., the first desalination plant near an Australian capital city and the first potable water recycling facility funded by state investment, were somewhat qualified successes. The desalination plant was never used to its full potential, even though community acceptance of desalinated water was much higher than for recycled water (Dolnicar and Schafer 2009, Hurlimann et al. 2009). The PRW plant, regarded as an emergency measure, was eventually not permitted to supplement the main reservoir supplies owing to perceived public suspicion of water re-use except in crisis situations. Similar outcomes had emerged in other Australian states, where governments explicitly ruled out the pursuit of PRW options owing to community fears that health risks were greater with PRW than with other potential sources of supply.

Thus, the Queensland state government embarked on a series of key decisions in 2006-2009 that put in place a portfolio of options for addressing the urban water crisis: demand management, organizational restructuring, new legislation, behavioral incentives, and expensive new infrastructure such as reservoir enlargement, regional pipelines, desalination, and PRW plants. This portfolio of measures provided (whether intentionally or accidentally) a well-balanced range of options for addressing water resilience and combating the drought in the immediate and longer terms. The knowledge base for considering options for water security and water sustainability had to transcend the historical data on rainfall and the traditional reliance on dam construction. The new options involved higher degrees of uncertainty. Complex technical issues and complex economic modeling were still required, but the policy choices had not been obvious, given the uncertain evidence about future rainwater, the uncertain effectiveness of incentives and targets in influencing behavioral change, and uncertainty about winners, losers, and trade-offs affecting the interests of water users and stakeholders.

Under these conditions of risk and uncertainty, political leaders chose to adopt closed decision-making processes rather than build on the collaborative initiatives associated with healthy waterways and catchment management groups. According to well-placed informants in the water sector, leaders were wary about sharing their decision-making options and their data with stakeholders and the general population. Some options were ruled out, such as major increases in water prices to curb consumption. There was no public inquiry process to investigate options for resolving the urban water crisis. Technical reports from consultants were commissioned to fill gaps, but the relative cost-effectiveness of options was not highlighted. Researchers elsewhere had demonstrated a wide variation in cost-effectiveness, ranging from small benefits (e.g., rainwater tank incentives) to substantial benefits (e.g., major infrastructure such as recycled water plants, desalination plants, and inter-regional pipelines; Young 2007). Ultimately, the state government opted for a suite of options, responding to a range of expert advice, taking a broad approach to risk management, and being mindful of the political need to gain support for water conservation and alternative water sources through effective communication with citizens and industry water users. However, the general public was not invited into the centralized discussion among trusted experts.

Until the 1980s, the technology and infrastructure approach had been regarded as sufficient to meet the challenges of flood mitigation and provision of potable water for the population of SEQ. In later decades, the technology paradigm became entwined with more complex issues of ecological and resource management 
and the future sustainability of city populations. There were corresponding shifts in the perceived problems demanding policy attention. From 2002, the evidence mounted that water supplies would be insufficient at current rates of water consumption, leading to pressure for new strategic directions such as demand management, water efficiency, and collective frameworks allowing trade-offs among stakeholder interests. These factors highlighted the social and institutional aspects of water policy and management that complement the engineering dimensions (Blomquist et al 2004, Colebatch 2006). The policy system had to shift some way toward recognizing the contributions of a broader range of expertise and had to indicate the benefits of inducing cooperative behavior among stakeholder groups. Stakeholder networks and stakeholder expertise have become crucial internationally for achieving politically feasible outcomes in water management (Freeman 2000, Connick and Innes 2001, Huitema et al 2009, Booher and Innes 2010, Wallington et al. 2012) by reducing conflict and allowing a greater role for consensus formation in the policy system. However, this insight has not yet been formally recognized in the water planning processes for SEQ.

The SEQ case suggests that drought, flood, and catchment ecology issues did not sit easily together in strategic policy frameworks and that the expert policy communities for these issues remained separated. The experts in "pipes and dams" were different from those who dealt with healthy rivers or with emergency management. Recent policy debates about the significance of climate change, and the policy implications of climate change and variability, have reinforced the need to take knowledge-sharing approaches more seriously in natural resource management. There is increasing value in facilitating the development of forums or intermediary organizations that bring stakeholders together, that provide opportunities for discussion of divergent viewpoints, or that share research findings with policymakers and practitioners (Clark et al. 2010). In recent years, the development of the SEQ regional planning framework has provided a space for many issues to be recognized (Queensland Government 2009), but there is no clear responsibility for a coordinated approach. This regional framework, while invoking the holistic language of regional resilience and sustainability, continues to place economic growth and physical infrastructure as the central objectives, with secondary attention to socialecological sustainability. The inherent tensions in integrating and coordinating these contradictory policy directions remain unresolved, especially in the absence of robust civic engagement concerning future directions in policy governance.

\section{CONCLUSION}

Using this case study, I have considered the knowledge base deployed for water planning and decision-making, the capacity for adaptive policy learning across crisis periods, and the collaborative governance arrangements that might be required for managing complex and rapidly evolving issues. Policy problems are framed or constructed by the process of debate, but some policy areas (those seen as technical issues) are more closed than others. Water management has been a relatively closed policy network confined to technical experts. Recent trends and challenges indicate that policy networks needed to expand to deal more effectively with the range of associated social, economic, environmental, and institutional issues. Regional resilience was proclaimed as a policy goal, for both water security and for flood protection, but the practices remained largely anchored in traditional technical frameworks. Research on social-ecological resilience seeks to understand and assess the capacity of a system to respond successfully to major stresses, disturbances, or crises, and to identify the effectiveness of relevant policy, regulatory, and planning frameworks. The SEQ case calls into question the capacities of leaders to take timely and appropriate actions under crisis conditions.

The SEQ case study raises questions about how and whether learning opportunities are recognized and taken up by decisionmakers and stakeholders. Following the large flood of 1974, the new dam at Wivenhoe was described as flood mitigation infrastructure and became widely regarded as having floodproofed Brisbane. Over time, as the immediacy of flood experience diminished, the collective sense of security increased. As noted in other cases of community and government responses to natural disasters (Colten and Sumpter 2009, Colten and Giancarlo 2011), social memory of disasters may tend to shift over time as the immediacy of experience fades. Finding comfort in business-as-usual assumptions may re-emerge. The widespread assumption in SEQ that flood problems had been solved was contradicted by the major flooding of early 2011, the ramifications of which will be debated for some time (Queensland Floods Commission of Inquiry 2012). On the other hand, in relation to the creeping crisis of urban water supplies from 2002, political leaders were slow to take strategic action until the prospect of a disaster finally provoked a sudden urge to find rapid solutions. The crisis generated calls for decisive political leadership and expert-driven advice in response to increased levels of civic anxiety and critical public commentary. During this crisis period, the broader water quality agenda championed by the Healthy Waterways Partnership (2007) and the holistic approach to sustainability implied in the SEQ Regional Plan were sidelined while the supply-side crisis moved to the center stage of politics. The task was framed as drought-proofing the SEQ region. Centralized investment decisions and governance restructuring provoked conflict between the state and local levels of government, which in turn undermined the capacity to create more consensual approaches to problem-solving. In a context of low trust between these key stakeholders, cooperative discussions among professionals retreated to the safety of informal networks. The context of crisis decision-making was unfriendly to open dialog or inclusive debate, even though long-term strategies seemed to require such inclusiveness.

Traditional infrastructure options remained the starting point, but these were eventually shown to be insufficient. The range of policy options considered by government expanded considerably in this period. Importantly, there was a new reliance on demand management in the most critical two years while new infrastructure solutions were being constructed. Water conservation became an important theme in setting community norms. Some elements of an emergent new paradigm were becoming evident. Decision-makers favored policies that would provide quick results, and international firms eagerly offered to build desalination plants and wastewater recycling plants (Khan 2008). The most surprising, and politically courageous, initiative was the state Premier's announcement that potable recycled water would be mixed with standard reservoir supplies. This promise was not fulfilled owing to changes in the context of decision- 
making with the return of rainfall two years later. Once normal conditions returned, the collective desire for business-as-usual became evident: major new infrastructure facilities were not fully used, or even were closed, and journalists began to suggest that they had been expensive mistakes. The government countered that the additional capacity was necessary insurance to drought-proof SEQ. In contrast, in relation to the flood events and subsequent Commission of Inquiry, the preoccupation with the blame game and with the adequacy of insurance cover served to side-track more fundamental issues such as incompatible land use in floodprone areas. International experience suggests that working with the inevitability of floods will lead to better land-use planning and improved contingency planning(Jonkman and Dawson 2012, Tierney 2012).

This case study of SEQ illustrates that paradigm shifts do not necessarily follow a progressive sequence and that the factors that trigger or facilitate some initial steps forward may not be helpful in moving toward further steps. Transition theory (Loorbach 2010) suggests that long-term shifts between paradigms tend to evolve in phases and at various activity levels. Although it may be possible to detect elements of a sequence (take-off, acceleration, and stabilization) in some mature examples of water and energy system innovation in Europe, as suggested by Loorbach (2010), the pattern of water policy innovation in SEQ has been different: uneven, contested, and "two steps forward, one step backward" in several aspects. Incremental change, within a technical paradigm, appears to have survived as the dominant approach despite the very real innovations described above. The factors that reinforced path dependency were temporarily challenged. However, the crisis events that triggered innovation and an opportunity for new thinking did not provide the institutional and other conditions that would sustain system innovation toward sustainability goals. In particular, the crises of drought and flood sparked new options and undermined old assumptions, but did not generate and consolidate institutional capacity to plan collaboratively for the future.

Responses to this article can be read online at: http://www.ecologyandsociety.org/issues/responses. $\mathrm{php} / 6414$

\section{Acknowledgments:}

I thank the anonymous reviewers whose thoughtful comments led to major improvements. I also thank several research associates working on water and natural resource issues between 2009 and 2012, and colleagues at conferences in Lund, Bern, Tempe, Brisbane, Canberra, and Melbourne, where earlier versions of some of these ideas were presented. Some of the interview materials used to chart the complex issues outlined in this case study were gathered in projects with Drs. Tabatha Wallington, Vikki Uhlmann, Jenny Bellamy, Helen Ross, Kelly Fielding, and Vicki Ross. Some elements of this research were supported by grants from the Urban Water Security Research Alliance (2008-2010), the Australian Research Council (2010-2012), and the Cooperative Research Centre for Water-sensitive Cities (2013).

\section{LITERATURE CITED}

Allison, H. E., and R. J. Hobbs. 2004. Resilience, adaptive capacity, and the "lock-in trap" of the Western Australian agricultural region. Ecology and Society 9(1): 3. [online] URL: http://www.ecologyandsociety.org/vol9/iss1/art3/.

Australian Government. 2004. National water initiative. Australian Government, Canberra, Australia. [online] URL: http://www.nwc.gov.au/nwi.

Australian Government. 2008. Murray-Darling basin reform. Australian Government, Canberra, Australia. [online] URL: http://www.coag.gov.au/sites/default/files/Murray_Darling_IGA. pdf.

Blomquist, W., T. Heikkila, and E. Schlager. 2004. Building the agenda for institutional research in water resource management. Journal of the American Water Resources Association 40 (4):925-936. http://dx.doi.org/10.1111/j.1752-1688.2004.tb01056. $\underline{\mathrm{X}}$

Bohensky, E. L. 2008. Discovering resilient pathways for South African water management: two frameworks for a vision. Ecology and Society 13(1): 19. [online] URL: http://www.ecologyandsociety. org/vol13/iss 1/art19/.

Booher, D. E., and J. E. Innes. 2010. Governance for resilience: CALFED as a complex adaptive network for resource management. Ecology and Society 15(3): 35. [online] URL: $\underline{\text { http:// }}$ www.ecologyandsociety.org/vol15/iss3/art35/.

Bos, J. J., and R. R. Brown. 2012. Governance experimentation and factors of success in socio-technical transitions in the urban water sector. Technological Forecasting and Social Change 79 (7):1340-1353. http://dx.doi.org/10.1016/j.techfore.2012.04.006

Brown, K., and E. Westaway. 2011. Agency, capacity, and resilience to environmental change: lessons from human development, well-being, and disasters. Annual Review of Environment and Resources 36:321-342. http://dx.doi.org/10.1146/ annurev-environ-052610-092905

Brown, R. R., N. Keath, and T. H. F. Wong. 2009. Urban water management in cities: historical, current and future regimes. Water Science and Technology 59(5):847-855. http://dx.doi. org/10.2166/wst.2009.029

Caulfield, J., and J. Wanna, editors. 1995. Power and politics in the city: Brisbane in transition. Macmillan, Melbourne, Australia.

Clark, W. C., T. P. Tomich, M. van Noordwijk, N. M. Dickson, D. Catacutan, D. Guston, and E. McNie. 2010. Toward a general theory of boundary work: insights from the CGIAR's natural resource management programs. Center for International Development Working Paper 199. Harvard University, Cambridge, Massachusetts, USA. [online] URL: http://www.hks. harvard.edu/centers/cid/publications/faculty-working-papers/cidworking-paper-no.-199.

Cole, J. R. 1984. Shaping a city: Greater Brisbane 1925-1985. William Brooks, Brisbane, Australia.

Colebatch, H. K. 2006. Governing the use of water: the institutional context. Desalination 187(1-3):17-27. http://dx.doi. org/10.1016/j.desal.2005.04.064 
Colten, C. E., and A. Giancarlo. 2011. Losing resilience on the Gulf Coast: hurricanes and social memory. Environment: Science and Policy for Sustainable Development 53(4):6-19. http://dx.doi. org/10.1080/00139157.2011.588548

Colten, C. E., and A. R. Sumpter. 2009. Social memory and resilience in New Orleans. Natural Hazards 48(3):355-364. http:// dx.doi.org/10.1007/s11069-008-9267-x

Connell, D. 2007. Water politics in the Murray-Darling basin. Federation Press, Sydney, Australia.

Connick, S., and J. Innes. 2001. Outcomes of collaborative water policy making: applying complexity thinking to evaluation. Working Paper 2001-08. Institute of Urban and Regional Development, University of California, Berkeley, California, USA. [online] URL: http://citeseerx.ist.psu.edu/viewdoc/download? $\underline{\text { doi }=10.1 .1 .118 .7996 \& r e p=r e p 1 \& t y p e ~}=$ pdf.

Dolnicar, S., and A. I. Schafer. 2009. Desalinated versus recycled water: public perceptions and profiles of the accepters. Journal of Environmental Management 90(2):888-900. http://dx.doi.org/10.1016/ j.jenvman.2008.02.003

Dovers, S., and S. Wild River, editors. 2003. Managing Australia's environment. Federation Press, Sydney, Australia.

European Commission. 2000. Directive 2000/60/EC of the European Parliament and of the Council establishing a framework for the Community action in the field of water policy. European Commission, Brussels, Belgium. [online] URL: http://eur-lex. europa.eu/legal-content/EN/TXT/?uri=CELEX:32000L0060.

European Commission. 2009. Common implementation strategy for the Water Framework Directive (2000/60/EC). Guidance document no. 24: river basin management in a changing climate. European Commission, Brussels, Belgium. [online] URL: http:// www.sednet.org/download/directive climate adaptation management climate.pdf.

Folke, C. 2006. Resilience: the emergence of a perspective for social-ecological systems analyses. Global Environmental Change 16(3):253-267. http://dx.doi.org/10.1016/j.gloenvcha.2006.04.002

Freeman, D. M. 2000. Wicked water problems: sociology and local water organizations in addressing water resources policy. Journal of the American Water Resources Association 36 (3):483-491. http://dx.doi.org/10.1111/j.1752-1688.2000.tb04280. $\underline{\mathrm{X}}$

Gallopín, G. C. 2006. Linkages between vulnerability, resilience, and adaptive capacity. Global Environmental Change 16 (3):293-303. http://dx.doi.org/10.1016/j.gloenvcha.2006.02.004

Gleeson, B., and W. Steele, editors. 2010. A climate for growth: planning South-east Queensland. University of Queensland Press, Brisbane, Australia.

Gleick, P. H. 2000. A look at twenty-first century water resources development. Water International 25(1):127-138. http://dx.doi. org/10.1080/02508060008686804

Global Water Partnership. 2000. Integrated water resource management. TAC Background Paper 4. Global Water Partnership Secretariat, Stockholm, Sweden.
Global Water Partnership. 2008. Climate change adaptation and integrated water resource management: an initial overview. Global Water Partnership, Stockholm, Sweden.

Godschalk, D. R. 2003. Urban hazard mitigation: creating resilient cities. Natural Hazards Review 4(3):136-143. http://dx. doi.org/10.1061/(ASCE)1527-6988(2003)4:3(136)

Harvey, D. 1989. From managerialism to entrepreneurialism: the transformation in urban governance in late capitalism. Geografiska Annaler: Series B, Human Geography 71(1):3-17. http://dx.doi.org/10.2307/490503

Head, B. W. 2008. Three lenses of evidence-based policy. Australian Journal of Public Administration 67(1):1-11. http://dx. doi.org/10.1111/j.1467-8500.2007.00564.x

Head, B. W. 2010. Water policy-evidence, learning and the governance of uncertainty. Policy and Society 29(2):171-180. http://dx.doi.org/10.1016/j.polsoc.2010.03.007

Head, B. W., and J. Alford. 2014. Wicked problems: implications for public policy and management. Administration and Society, in press. http://dx.doi.org/10.1177/0095399713481601

Healey, P., C. de Magalhaes, A. Madanipour, and J. Pendlebury. 2003. Place, identity and local politics: analysing initiatives in deliberative governance. Pages 60-87 in M. A. Hajer and $\mathrm{H}$. Wagenaar, editors. Deliberative policy analysis: understanding governance in the network society. Cambridge University Press, Cambridge UK. http://dx.doi.org/10.1017/CBO9780511490934.004

Healthy Waterways Partnership. 2007. South East Queensland healthy waterways strategy 2007-2012. Healthy Waterways Partnership, Brisbane, Australia. [online] URL: http://www. healthywaterways.org/TheStrategy.aspx.

Holtz, S. 2009. Water policy: changing course for the soft path. Pages 73-84 in D. B. Brooks, O. M. Brandes, and S. Gurman, editors. Making the most of the water we have: the soft path approach to water management. Earthscan, London, UK.

Huitema, D., E. Mostert, W. Egas, S. Moellenkamp, C. PahlWostl, and R. Yalcin. 2009. Adaptive water governance: assessing the institutional prescriptions of adaptive (co)-management from a governance perspective and defining a research agenda. Ecology and Society 14(1): 26. [online] URL: http://www.ecologyandsociety. org/vol14/iss1/art26/.

Hurlimann, A., S. Dolnicar, and P. Meyer. 2009. Understanding behaviour to inform water supply management in developed nations - A review of literature, conceptual model and research agenda. Journal of Environmental Management 91(1):47-56. http://dx.doi.org/10.1016/j.jenvman.2009.07.014

Hussey, K., and S. Dovers, editors. 2007. Managing water for Australia: the social and institutional challenges. CSIRO, Melbourne, Australia.

Jonkman, S. N., and R. J. Dawson. 2012. Issues and challenges in flood risk management - editorial for the special issue on flood risk management. Water 4(4):785-792. http://dx.doi.org/10.3390/ $\underline{\mathrm{w} 4040785}$ 
Khan, S. 2008. Urban reuse and desalination. Pages 184-201 in L. Crase, editor. Water policy in Australia: the impact of change and uncertainty. Resources for the Future, Washington, D.C., USA.

Kingdon, J. W. 1995. Agendas, alternatives and public policies. Second edition. HarperCollins, New York, New York, USA.

Kiparsky, M., A. Milman, and S. Vicuña. 2012. Climate and water: knowledge of impacts to action on adaptation. Annual Review of Environment and Resources 37:163-194. http://dx.doi. org/10.1146/annurev-environ-050311-093931

Krysanova, V., H. Buiteveld, D. Haase, F. F. Hattermann, K. van Niekerk, K. Roest, P. Martínez-Santos, and M. Schlüter. 2008. Practices and lessons learned in coping with climatic hazards at the river-basin scale: floods and drought. Ecology and Society 13 (2): 32. [online] URL: http://www.ecologyandsociety.org/vol13/ iss $2 / \operatorname{art} 32 /$.

Lach, D., S. Rayner, and H. Ingram. 2005. Taming the waters: strategies to domesticate the wicked problems of water resource management. International Journal of Water 3(1):1-17. http://dx. doi.org/10.1504/IJW.2005.007156

Loorbach, D. 2010. Transition management for sustainable development: a prescriptive, complexity-based governance framework. Governance 23(1):161-183. http://dx.doi.org/10.1111/ j.1468-0491.2009.01471.x

McGowan, J. 2012. A missed opportunity to promote community resilience? The Queensland Floods Commission of Inquiry. Australian Journal of Public Administration 71(3):355-363. http:// dx.doi.org/10.1111/j.1467-8500.2012.00778.x

Miller, F., H. Osbahr, E. Boyd, F. Thomalla, S. Bharwani, G. Ziervogel, B. Walker, J. Birkmann, S. van der Leeuw, J. Rockström, J. Hinkel, T. Downing, C. Folke, and D. Nelson. 2010. Resilience and vulnerability: complementary or conflicting concepts? Ecology and Society 15(3): 11. [online] URL: http://www. ecologyandsociety.org/vol15/iss3/art11/.

Molden, D., editor. 2007. Water for food, water for life: comprehensive assessment of water management in agriculture. Earthscan, London, UK.

National Climate Change Adaptation Research Facility. 2013. Emergency management and climate change adaptation. Policy Guidance Brief 10. NCCARF, Gold Coast, Australia. [online] URL: http://www.nccarf.edu.au/publications/policy-guidancebrief-emergency-management.

Norris, F. H., S. P. Stevens, B. Pfefferbaum, K. F. Wyche, and R. L. Pfefferbaum. 2008. Community resilience as a metaphor, theory, set of capacities, and strategy for disaster readiness. American Journal of Community Psychology 41(1-2):127-150. http://dx.doi.org/10.1007/s10464-007-9156-6

Pahl-Wostl, C. 2008. Requirements for adaptive water management. Pages 1-22 in C. Pahl-Wostl, P. Kabat, and J. Möltgen, editors. Adaptive and integrated water management: coping with complexity and uncertainty. Springer, Berlin, Germany. http://dx.doi.org/10.1007/978-3-540-75941-6 1

Pahl-Wostl, C. 2009. A conceptual framework for analysing adaptive capacity and multi-level learning processes in resource governance regimes. Global Environmental Change 19(3):354-365. http://dx.doi.org/10.1016/j.gloenvcha.2009.06.001

Peters, G. B. 2005. The problem of policy problems. Journal of Comparative Policy Analysis 7(4):349-370. http://dx.doi. org/10.1080/13876980500319204

Pierson, P. 2000. Increasing returns, path dependence, and the study of politics. American Political Science Review 94 (2):251-267. http://dx.doi.org/10.2307/2586011

Pigram, J. J. 2007. Australia's water resources: from use to management. Revised edition. CSIRO, Melbourne, Australia.

Prime Minister's Science Engineering and Innovation Council. 2007. Water for our cities: building resilience in a climate of uncertainty. Department of Innovation, Canberra, Australia. [online] URL: http://www.innovation.gov.au/science/PMSEIC/ Documents/WaterforOurCities.pdf.

Productivity Commission. 2008. Towards urban water reform: a discussion paper. Productivity Commission, Canberra, Australia. [online] URL: http://www.pc.gov.au/research/commission/urbanwater-reform.

Pullar, I., and M. Cook. 2001. Watery sauces: a people's history of the Water Resources Commission (Queensland) and its predecessors 1881-1995. Department of Natural Resources and Mines, Brisbane, Australia.

Queensland Floods Commission of Inquiry. 2012. Final report. Queensland Floods Commission of Inquiry, Brisbane, Australia. [online] URL: http://www.floodcommission.qld.gov.au/publications/ final-report.

Queensland Government. 2004. Southeast Queensland regional water supply strategy. Stage 1 report, October 2004. Department of Natural Resources and SEQ Regional Organisation of Councils, Brisbane, Australia.

Queensland Government. 2005. South East Queensland regional water supply strategy. Stage 2 interim report, November 2005. Department of Natural Resources and SEQ Council of Mayors, Brisbane, Australia.

Queensland Government. 2009. South East Queensland regional plan 2009-2031. State of Queensland, Brisbane, Australia. [online] URL: http://www.dsdip.qld.gov.au/resources/plan/seq/ regional-plan-2009/seq-regional-plan-2009.pdf.

Queensland Water Commission. 2007. Our water: urban water supply arrangements in Southeast Queensland. Queensland Water Commission, Brisbane, Australia.

Queensland Water Commission. 2010. Southeast Queensland water strategy. Queensland Water Commission, Brisbane, Australia. [online] URL: http://www.dews.qld.gov.au/ data/ assets/pdf file/0019/80434/seqws.pdf.

Ragin, C. C., and H. S. Becker, editors. 1992. What is a case? Exploring the foundations of social inquiry. Cambridge University Press, Cambridge, UK.

Sabatier, P. A., editor. 2007. Theories of the policy process. Second edition. Westview Press, Boulder, Colorado, USA. 
Sadler, R. 1998. The Australian experience: managing a nonmetropolitan urban water utility - paradigm shifting towards a new mindset. International Journal of Public Sector Management 11(7):596-610. http://dx.doi.org/10.1108/09513559810247948

Spearritt, P., and B. W. Head. 2010. Water politics. Pages 88-107 in B. Gleeson and W. Steele, editors. A climate for growth: planning South-east Queensland. University of Queensland Press, Brisbane, Australia.

Tierney, K. 2012. Disaster governance: social, political, and economic dimensions. Annual Review of Environment and Resources 37:341-363. http://dx.doi.org/10.1146/annurevenviron-020911-095618

Troy, P. N., editor. 2008. Troubled waters: confronting the water crisis in Australia's cities. ANU E-Press, Canberra, Australia.

Turner, A., G. Hausler, N. Carrard, A. Kazaglis, S. White, A. Hughes, and T. Johnson. 2007. Review of water supply-demand options for Southeast Queensland: final report. Report for Mary River Council of Mayors. Institute for Sustainable Futures, Sydney, Australia. [online] URL: http://cfsites1.uts.edu.au/find/ isf/publications/Turneretal2007reviewwaterSEQ.pdf.

Uhlmann, V., and B. W. Head. 2011. Water recycling: recent history of local government initiatives in South East Queensland. Technical Report 45. Urban Water Security Research Alliance, Brisbane, Australia. [online] URL: http://www.urbanwateralliance. org.au/publications/UWSRA-tr45.pdf.

UNESCO. 2009. Water in a changing world: the third United Nations world water development report. Third edition. UNESCO, Paris, France. [online] URL: http://www.unesco.org/new/en/ natural-sciences/environment/water/wwap/wwdr/wwdr3-2009/.

Van den Honert, R. C., and J. McAneney. 2011. The 2011 Brisbane floods: causes, impacts and implications. Water 3(4):1149-1173. http://dx.doi.org/10.3390/w3041149

Van der Brugge, R., and J. Rotmans. 2007. Towards transition management of European water resources. Water Resources Management 21(1):249-267. http://dx.doi.org/10.1007/s11269-006-9052-0

Van der Brugge, R., J. Rotmans, and D. Loorbach. 2005. The transition in Dutch water management. Regional Environmental Change 5(4):164-176. http://dx.doi.org/10.1007/s10113-004-0086-7

Walker, B. H., N. Abel, J. M. Anderies, and P. Ryan. 2009. Resilience, adaptability, and transformability in the GoulburnBroken catchment, Australia. Ecology and Society 14(1): 12. [online] URL: http://www.ecologyandsociety.org/vol14/iss1/ art12/.

Walker, B. H., and D. Salt. 2006. Resilience thinking: sustaining ecosystems and people in a changing world. Island Press, Washington, D.C., USA.

Wallington, T., C. Robinson, and B. Head. 2012. Crisis, change and water institutions in south-east Queensland: strategies for an integrated approach. Pages 185-198 in T. Measham and S. Lockie, editors. Risk and social theory in environmental management. CSIRO, Melbourne, Australia.

Weber, E. P., and A. M. Khademian. 2008. Wicked problems, knowledge challenges, and collaborative capacity builders in network settings. Public Administration Review 68(2):334-349. http://dx.doi.org/10.1111/j.1540-6210.2007.00866.x

Yin, R. K. 2009. Case study research: design and methods. Fourth edition. Sage, Thousand Oaks, California, USA.

Young, M. 2007. Linking rural and urban water systems. Pages 85-95 in K. Hussey and S. Dovers, editors. Managing water for Australia: the social and institutional challenges. CSIRO, Melbourne, Australia. 